\title{
Expansion of tumor-infiltrating lymphocytes and their potential for application as adoptive cell transfer therapy in human breast cancer
}

\author{
Hee Jin Lee ${ }^{1, *}$, Young-Ae Kim ${ }^{1,2, *}$, Chan Kyu Sim ${ }^{3, *}$, Sun-Hee Heo ${ }^{1,2}$, In Hye Song ${ }^{1}$, \\ Hye Seon Park ${ }^{1,2}$, Suk Young Park ${ }^{1,2}$, Won Seon Bang ${ }^{1,2}$, In Ah Park ${ }^{1}$, Miseon Lee ${ }^{1}$, \\ Jung Hoon Lee ${ }^{3}$, Yeon Sook $\mathrm{Cho}^{3}$, Suhwan Chang ${ }^{4}$, Jaeyun Jung ${ }^{4}$, Jisun Kim ${ }^{5}$, Sae \\ Byul Lee ${ }^{5}$, Sung Youl Kim6, Myeong Sup Lee ${ }^{3, \#}$ and Gyungyub Gong ${ }^{5, \#}$ \\ ${ }^{1}$ Department of Pathology, University of Ulsan College of Medicine, Asan Medical Center, Seoul, Korea \\ ${ }^{2}$ Asan Center for Cancer Genome Discovery, Asan Institute for Life Sciences, University of Ulsan College of Medicine, Asan \\ Medical Center, Seoul, Korea \\ ${ }^{3}$ Lab of Molecular Immunology and Medicine, Department of Biomedical Sciences, University of Ulsan College of Medicine, \\ Seoul, Korea \\ ${ }^{4}$ Department of Biomedical Sciences, University of Ulsan College of Medicine, Seoul, Korea \\ ${ }^{5}$ Department of Surgery, University of Ulsan College of Medicine, Asan Medical Center, Seoul, Korea \\ ${ }^{6}$ R\&D Center, GNSBio Co. Ltd., Gyeonggi-do, Korea \\ *These authors contributed equally to this work \\ \#Authors share co-corresponding authorship \\ Correspondence to: Gyungyub Gong, email: gygong@amc.seoul.kr \\ Myeong Sup Lee, email: myeong@amc.seoul.kr
}

Keywords: breast cancer; tumor-infiltrating lymphocyte; adoptive cell transfer; memory T cell; function of TIL Received: July 12, $2017 \quad$ Accepted: November 13, $2017 \quad$ Published: December 06, 2017

Copyright: Lee et al. This is an open-access article distributed under the terms of the Creative Commons Attribution License 3.0 (CC BY 3.0), which permits unrestricted use, distribution, and reproduction in any medium, provided the original author and source are credited.

\section{ABSTRACT}

Adoptive cell transfer (ACT) of ex vivo expanded tumor-infiltrating lymphocytes (TILs) has been successful in treating a considerable proportion of patients with metastatic melanoma. In addition, some patients with several other solid tumors were recently reported to have benefited clinically from such ACT. However, it remains unclear whether ACT using TILs is broadly applicable in breast cancer, the most common cancer in women. In this study, the utility of TILs as an ACT source in breast cancers was explored by deriving TILs from a large number of breast cancer samples and assessing their biological potentials. We successfully expanded TILs ex vivo under a standard TIL culture condition from over 100 breast cancer samples, including all breast cancer subtypes. We also found that the information about the percentage of TIL and presence of tertiary lymphoid structure in the tumor tissues could be useful for estimating the number of obtainable TILs after ex vivo culture. The ex vivo expanded TILs contained a considerable level of central memory phenotype $\mathrm{T}$ cells (about $\mathbf{2 0 \%}$ ), and a large proportion of TIL samples were reactive to autologous tumor cells in vitro. Furthermore, the in vitro tumor-reactive autologous TILs could also function in vivo in a xenograft mouse model implanted with the primary tumor tissue. Collectively, these results strongly indicate that ACT using ex vivo expanded autologous TILs is a feasible option in treating patients with breast cancer.

\section{INTRODUCTION}

Breast cancer is the most common cancer in women, affecting about $12 \%$ worldwide, and causing more than 40,000 deaths per year in the United States alone $[1,2]$.
Breast cancer can be divided into subtypes according to the expression of hormone receptors (HRs; estrogen receptor (ER) and progesterone receptor (PR)) and human epidermal growth factor receptor 2 (HER2). Because breast cancer is such a heterogeneous disease, most therapeutic 
benefit usually comes from subtype-specific treatment [3]. Although survival rates after treatment have improved recently, largely owing to the advancement in neoadjuvant and adjuvant therapies [4], there are still a relatively large number of patients with treatment-resistant breast cancer [3, 5] for whom new therapeutic options are needed.

In recent years, cancer immunotherapy has emerged as an additional treatment alternative [6]. Popular cancer immunotherapeutic modalities include administration of monoclonal antibodies targeting immune checkpoints, tumor vaccination, and adoptive transfer of $\mathrm{T}$ cells engineered to have chimeric antigen receptors (CAR-T cells) or tumor-infiltrating lymphocytes (TILs), which target tumor cells [7]. Although not successful in all cases, a considerable proportion of patients treated with such immunotherapies have gained good clinical benefit, including complete remission for several years, which has popularized the approach as an anti-cancer modality $[8,9]$. Adoptive cell transfer (ACT) using TILs (adoptive TIL therapy) is one such immunotherapy. This therapy is based on ex vivo expansion of TILs from patients with cancer and reinfusion of the TILs into the patients; it was originally developed for treating patients with advanced melanoma [8]. Impressively, objective response rates of over $50 \%$ were observed in patients with metastatic melanoma after adoptive TIL therapy, and the complete remission rate reached up to $24 \%[8,10-12]$. When adoptive TIL therapy was applied to other solid tumors, including those of the uterus, cervix, lung, and gastrointestinal tract, some patients also showed excellent clinical responses [9, 13-15]. These results imply that other solid cancers, such as breast cancer, could be appropriate targets for the application of ACT; however, in breast cancer, extensive TIL cultures and evaluation of the therapeutic potential of adoptive TIL therapy have not been reported, although TIL culture is reported to be possible in breast cancer [16]. Furthermore, although the clinical importance of long-lived memory $\mathrm{T}$ cell subsets in ex vivo expanded TILs is well established in a number of cancers, in breast cancer the composition of memory $\mathrm{T}$ cell subsets among fresh TILs directly derived from cancer tissues and ex vivo expanded TILs has never been described [8, 17-19].

In this study, we successfully expanded TILs from breast tumor samples from over 100 individuals and showed that the expanded TILs containing central memory phenotype T cells could be useful as an ACT source.

\section{RESULTS}

\section{Successful TIL cultures are possible from all breast cancer subtypes}

Sources of TILs in ex vivo cultures are the cells within tumors and in the tertiary lymphoid structures (TLSs) in the tumor-adjacent tissue. Therefore, we first estimated the levels of TILs and TLSs in each subtype of breast cancer by analyzing hematoxylin and eosin (H\&E)-stained sections of cancer tissues from 198 patients (Supplementary Table 1). The percentage of TILs and the degree of TLSs within $\mathrm{HR}^{+}$/ $\mathrm{HER}^{-}$tissue were significantly lower than those in $\mathrm{HR}^{-}$/ $\mathrm{HER}^{+}{ }^{+}$or $\mathrm{HR}^{-} / \mathrm{HER} 2^{-}$triple-negative breast cancer (TNBC) subtypes (Figure 1A and 1B). However, the distributions of the percentage of TILs (median, $5 \%$; range, $1-80 \%$ in $\mathrm{HR}^{+} / \mathrm{HER}^{-}$; median, 20\%; range, $1-90 \%$ in $\mathrm{HR}^{+} / \mathrm{HER}^{+}$; median, 30\%; range, $1-80 \%$ in $\mathrm{HR}^{-} / \mathrm{HER}^{+}$; median, $10 \%$; range, $1-90 \%$ in TNBC) and the degree of TLS (median score 1 in $\mathrm{HR}^{+} / \mathrm{HER}^{-}$; median 2 in $\mathrm{HR}^{+} / \mathrm{HER}^{+}$; median 2.5 in $\mathrm{HR}^{-} / \mathrm{HER}^{+}$; median 2 in $\mathrm{TNBC}$; and score range 0-3 for all subtypes) within each subtype were quite broad (Figure 1A and 1B), indicating that the subtype itself cannot provide a good indication of the levels of TILs or TLS.

To apply adoptive TIL therapy to cancer treatment, TILs from tumors should first be expanded. To expand TILs ex vivo, tumor samples (on average 63 tumor fragments derived from each tumor of on average $6 \mathrm{~mm}$ in diameter and 2-3 mm thickness) from 187 patients with breast cancer of all subtypes were cultured under a standard initial TIL culture condition for 2 weeks (Materials and methods; Supplementary Table 2). Except in five cases, we were able to obtain $>1.0 \times 10^{3}$ TILs per tumor fragment; the majority of cases $(129 / 182)$ yielded $>1.0 \times 10^{5}$ TILs from each fragment (Supplementary Table 2). The number of TILs obtained from each breast cancer subtype was not significantly different among subtypes (median, $2.0 \times 10^{5}$; range, $0.03-68.8 \times 10^{5}$ in $\mathrm{HR}^{+} / \mathrm{HER}^{-}$; median, $3.6 \times 10^{5}$; range, 0.01-58.5 $\times 10^{5}$ in $\mathrm{HR}^{+} / \mathrm{HER}^{+}$; median, $4.8 \times 10^{5}$; range, $0.03-44.5 \times 10^{5}$ in $\mathrm{HR}^{-} / \mathrm{HER} 2^{+}$; median, $3.3 \times 10^{5}$; range, $0.01-66.7 \times 10^{5}$ in TNBC; Figure 1C). These results indicate that TILs can be stably obtained from the majority of breast cancers, regardless of subtype. Our samples were derived from patients treated both with and without neoadjuvant chemotherapy (NAC and No NAC, respectively; Supplementary Tables 1 and 2). After the initial 2 week culture of cells from both types of patient samples, the number of TILs obtained from NAC samples was significantly lower $\left(4.7 \pm 6.5 \times 10^{5}\right.$ vs. $8.9 \pm 13.9 \times 10^{5}$; $p<0.05)$ than that obtained from No NAC samples, indicating that chemotherapy reduced the mass of the tumor and/or number of TILs, but the degree of reduction was only slight (Figure 1D).

\section{TIL and TLS levels in tumor tissues provide a good indication of the TIL number obtainable after ex vivo culture}

To explore whether analysis of the cancer tissue before culture could be useful for predicting the obtainable TIL numbers after the initial 2 week culture, the percentage of TILs or degree of TLS was estimated histologically 
from cancer tissue sections (Materials and methods). The group with $\leq 5 \%$ TILs observed in the tumor tissue yielded a significantly lower number of cultured TILs than those groups $(10 \% \leq \mathrm{TIL} \leq 30 \%, 40 \% \leq \mathrm{TIL} \leq 60 \%$, or $70 \%$ $\leq$ TIL) with a higher percentage of TILs observed in the tissue, while the tumor group with $70 \% \leq$ TILs in tissues gave significantly higher numbers of cultured TILs than those groups with a lower percentage of TILs in tissues (Figure 2A, Supplementary Table 2). Similarly, tumors with abundant TLSs yielded significantly higher numbers of cultured TILs than those graded as having 'none', 'little', or 'moderate' TLS (Figure 2B, Supplementary Table 2). Consistently, there was a significant, positive correlation between the number of obtained TILs and the percentage of TILs in cancer tissues (correlation coefficient $\rho=0.527, p<0.001$ ), and between the number of obtained TILs and TLS degree (correlation coefficient $\rho=0.392, p<0.001$ ). Since both TIL percentage and TLS degree in tissues can affect the number of TILs obtained after 2 week culture, the number of obtained TILs was analyzed by simultaneously taking into account the TIL percentage and TLS degree for the same sample. As expected, the tumor group with the highest percentage of TILs observed in the tissue $(\geq 70 \%)$ and abundant TLSs yielded a much higher number of TILs after the 2 week culture than the groups with a low percentage of TILs $(\leq 5 \%)$ and none, little, moderate, or abundant TLSs, while the tumor group with the highest percentage of TILs $(\geq 70 \%)$ and a moderate degree of TLS yielded a much higher number of TILs after 2 weeks' culture than those
A

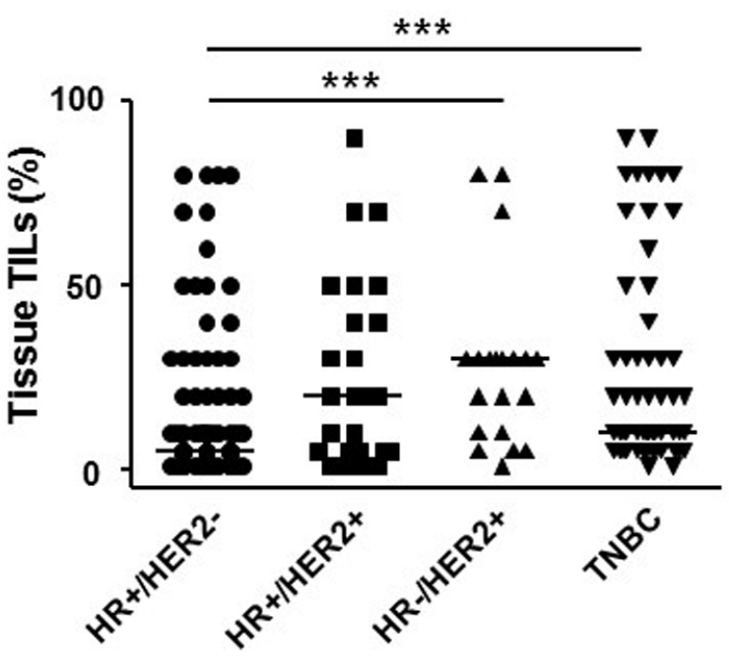

C

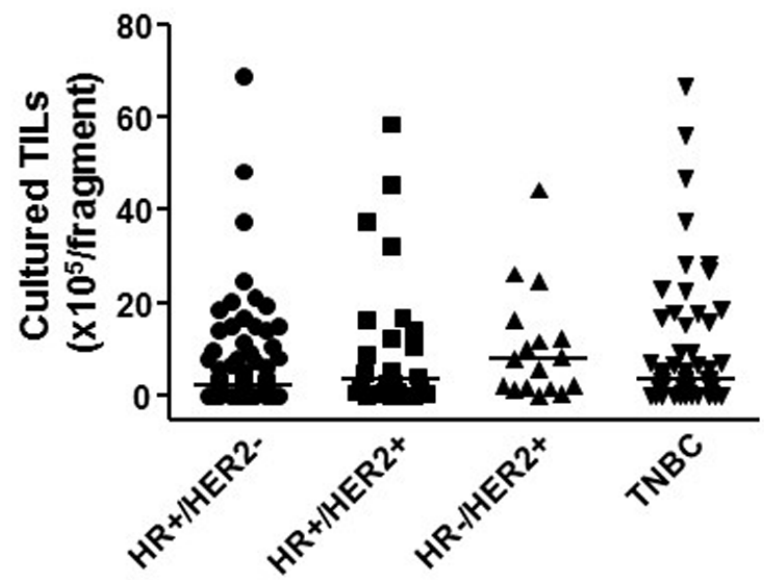

B

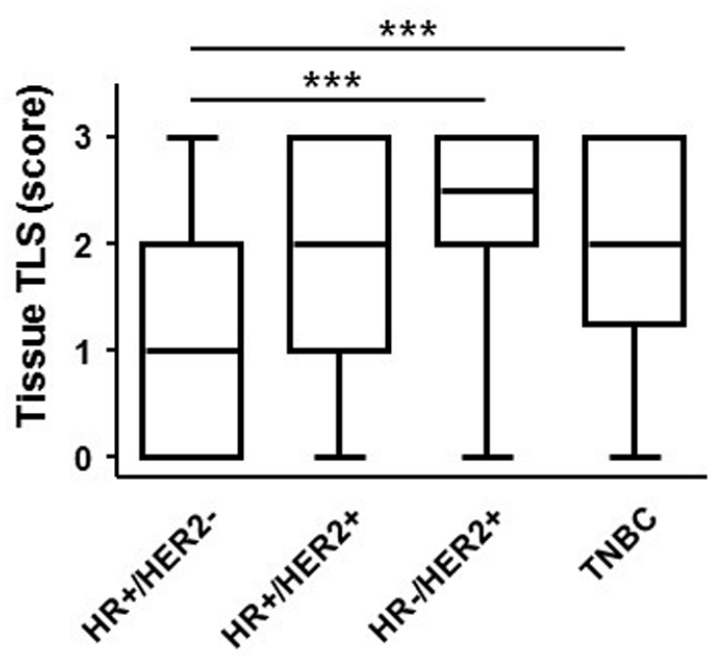

D

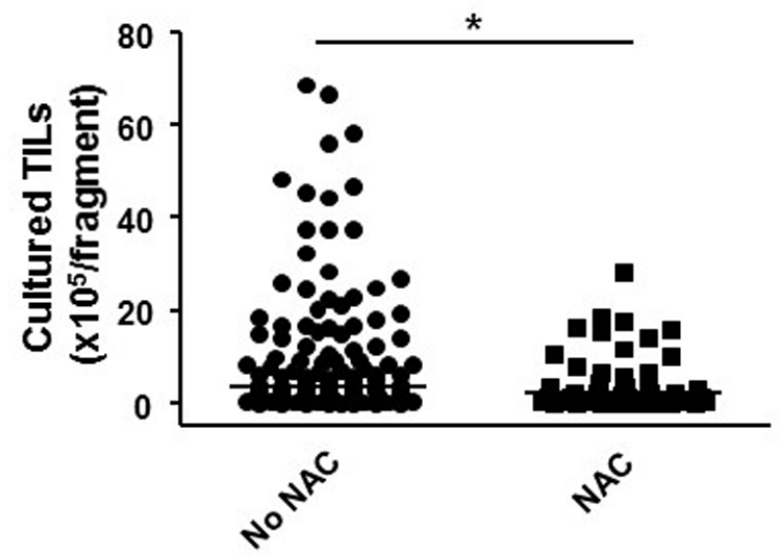

Figure 1: Tumor-infiltrating lymphocytes (TILs) from breast cancer tissues can be successfully expanded after 2 weeks' ex vivo culture. (A) Percentage (\%) of TILs and (B) degree (score) of tertiary lymphoid structure (TLS) in HR ${ }^{+} / \mathrm{HER} 2^{-}(n=95)$, $\mathrm{HR}^{+} / \mathrm{HER} 2^{+}(n=26), \mathrm{HR}^{-} / \mathrm{HER}^{+}(n=20)$, and TNBC $(n=56)$ breast cancer tissues. The degree of TLS was expressed as the following scores: 0, none; 1, little; 2, moderate; 3, abundant. (C) Number of TILs (per fragment) obtained after 2 weeks' ex vivo culture from HR ${ }^{+} /$ HER2 $^{-}(n=83), \mathrm{HR}^{+} / \mathrm{HER} 2^{+}(n=26), \mathrm{HR}^{-} / \mathrm{HER}^{+}(n=17)$, and TNBC $(n=56)$ breast cancer tissues. (D) Number of TILs (per fragment) obtained after 2 weeks' ex vivo culture from breast cancer tissues of patients treated with neoadjuvant chemotherapy (NAC) $(n=49)$ or without NAC (No NAC, $n=133$ ). Kruskal-Wallis test and Mann-Whitney $U$-test were used for statistical analysis. ${ }^{*} p<0.05,{ }^{* * *} p<0.01$, ${ }^{* * *} p<0.001$. HR, hormone receptor; TNBC, triple-negative breast cancer. 
groups with a low percentage of TILs $(\leq 5 \%)$ and a little or moderate degree of TLS (Figure 2C and 2D).

The minimum number of TILs required for ACT in a clinical setting is around $1 \times 10^{10}$ per patient [20-22]. The standard rapid expansion protocol (REP), a second round of culture after the 2 week initial culture, can expand TILs
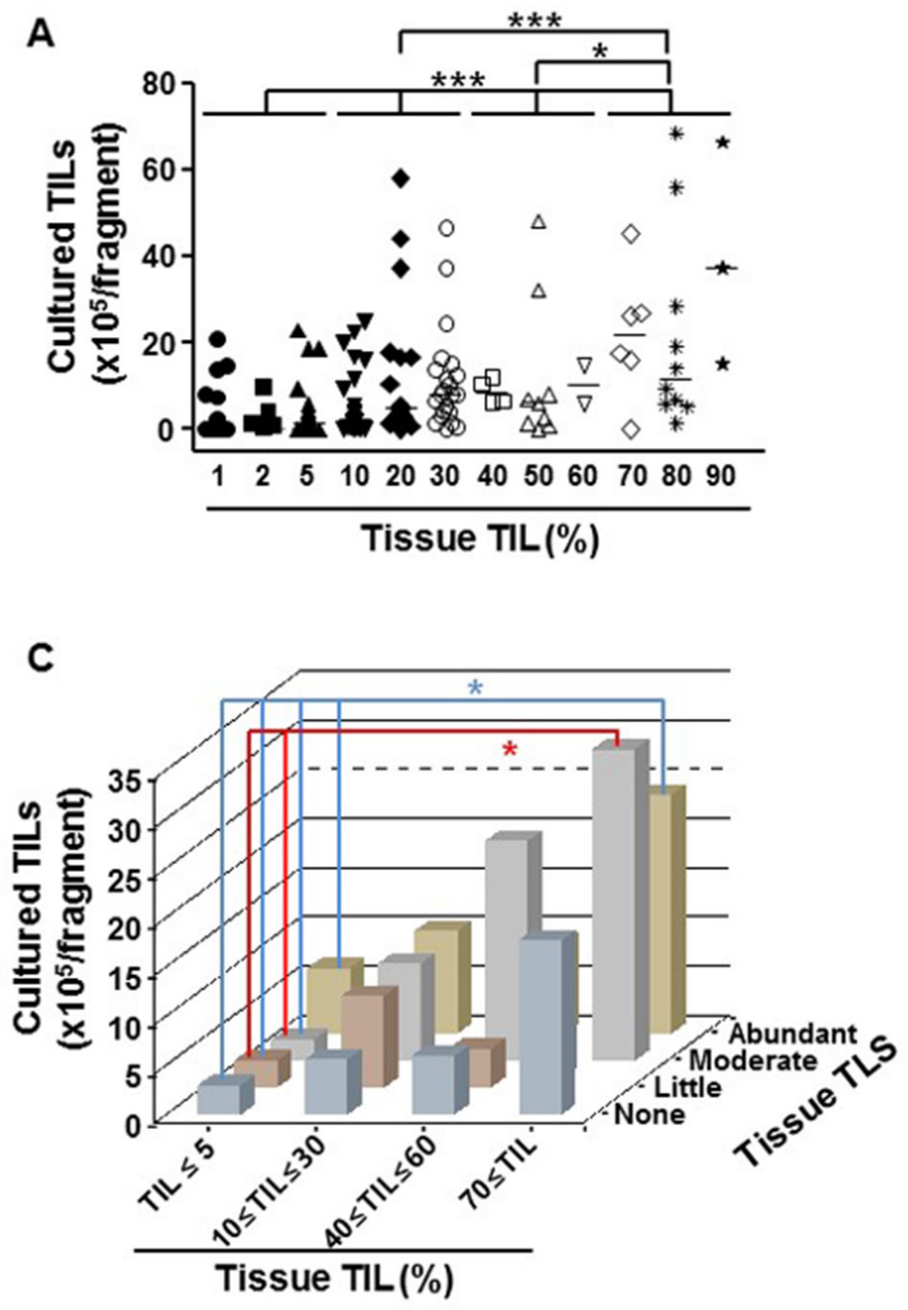

by 1,000-fold [23], and the usual obtainable tumor samples ( $\geq 8 \mathrm{~mm}$ in diameter and $2-3 \mathrm{~mm}$ thickness) can provide more than 100 fragments; thus if $>1.0 \times 10^{5}$ TILs are obtainable from each tumor fragment after only the initial 2 weeks' culture, sufficient TILs for ACT in an autologous patient would be expected after the standard REP.
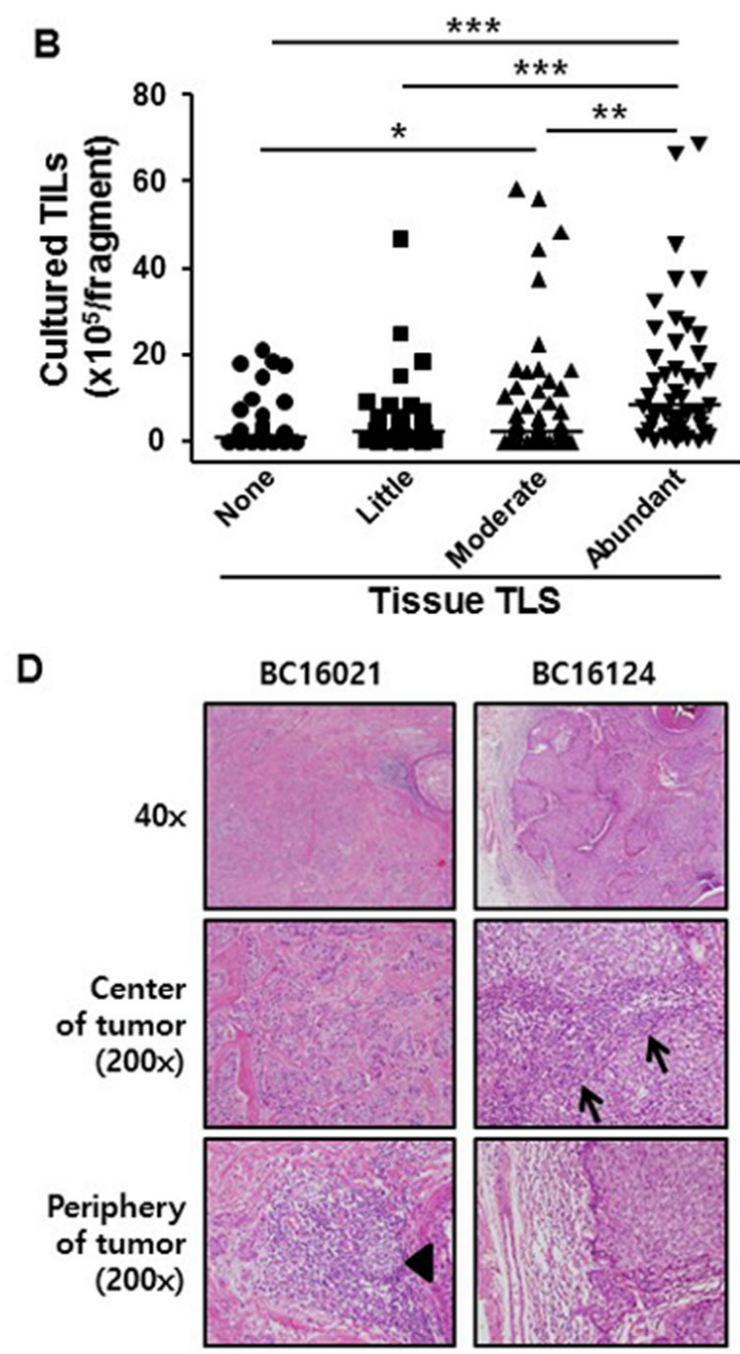

Figure 2: Correlation between the number of 2 week TILs and TIL percentage or TLS degree in breast cancer tissues. (A) The number of TILs per fragment ( $y$-axis) obtained after 2 weeks' ex vivo culture from breast cancer tissues was plotted against histologically determined tissue TIL percentage ( $x$-axis): Tissue TILs: $1 \%(n=29), 2 \%(n=5), 5 \%(n=45), 10 \%(n=26), 20 \%(n=19)$, $30 \%(n=22), 40 \%(n=4), 50 \%(n=9), 60 \%(n=2), 70 \%(n=6), 80 \%(n=10)$, and $90 \%(n=3)$. Tumor samples were grouped as follows for statistical analysis: TILs $\leq 5 \%, 10 \% \leq$ TIL $\leq 30 \%, 40 \% \leq$ TIL $\leq 60 \%$, or $70 \% \leq$ TIL. (B) The number of TILs per fragment $(y$-axis) obtained after the 2 week culture was plotted against tissue TLS degree ( $x$-axis) grouped as follows: Tissue TLS degree, none $(n=42)$, little $(n=35)$, moderate $(n=56)$, and abundant $(n=47)$. (C) The average number of TILs per fragment $(z$-axis) obtained after the 2 week culture was plotted in the space defined by both percentage of tissue TILs ( $x$-axis) and TLS degree ( $y$-axis) in the same sample: $1 \% \leq$ tissue TILs $\leq 5 \%$ and TLS none $(n=36) ; 1 \% \leq$ tissue TILs $\leq 5 \%$ and TLS little $(n=19) ; 1 \% \leq$ tissue TILs $\leq 5 \%$ and TLS moderate $(n=19) ; 1 \% \leq$ tissue TILs $\leq 5 \%$ and TLS abundant $(n=5) ; 10 \% \leq$ tissue TILs $\leq 30 \%$ and TLS none $(n=4) ; 10 \% \leq$ tissue TILs $\leq 30 \%$ and TLS little $(n=14)$; $10 \% \leq$ tissue TILs $\leq 30 \%$ and TLS moderate $(n=32) ; 10 \% \leq$ tissue TILs $\leq 30 \%$ and TLS abundant $(n=17) ; 40 \% \leq$ tissue TILs $\leq 60 \%$ and TLS none $(n=1) ; 40 \% \leq$ tissue TILs $\leq 60 \%$ and TLS little $(n=2) ; 40 \% \leq$ tissue TILs $\leq 60 \%$ and TLS moderate $(n=3) ; 40 \% \leq$ tissue TILs $\leq 60 \%$ and TLS abundant $(n=9) ; 70 \% \leq$ tissue TILs and TLS none $(n=1) ; 70 \% \leq$ tissue TILs and TLS little $(n=0) ; 70 \% \leq$ tissue TILs and TLS moderate $(n=2)$; and $70 \% \leq$ tissue TILs and TLS abundant $(n=16)$. Kruskal-Wallis test and Mann-Whitney $U$-test were used for statistical analysis. ${ }^{*} p<0.05,{ }^{* *} p<0.01,{ }^{* * *} p<0.001$. (D) Representative examples of H\&E sections showing low numbers of TILs (5\%) and little TLS (left panels: sample BC16021, $18.7 \times 10^{5} \mathrm{TILs} /$ fragment obtained after 2 weeks' culture), and high numbers of TILs (70\%) and no TLS (right panels: sample BC16124, $17.7 \times 10^{5} \mathrm{TILs} /$ fragment obtained after culture). Arrows indicate TILs, and the arrowhead indicates TLS. 
When the distribution of the number of TILs obtained from one tumor fragment after 2 weeks' culture was analyzed by simultaneously taking into account the TIL percentage and TLS degree for the same sample, interestingly, the majority of tumor fragments with $\geq 10 \%$ TILs (regardless of TLS level; in 87/102 cases) or with abundant TLS (regardless of TIL percentage; in 44/48 cases) yielded more than $1.0 \times 10^{5}$ TILs after 2 weeks' culture (Figure 2C, Supplementary Table 2). These results suggest that TIL percentage and TLS degree in tumor tissues are very informative for predicting the number of easily obtainable TILs, which would be important for planning a schedule for ACT with ex vivo expanded TILs.

\section{Memory phenotype $T$ cells are the major subset after TIL culture}

Production of large numbers of TILs is necessary for ACT therapy, and therefore the REP is usually required. When such expansion was performed with the TILs obtained after the initial 2 weeks' culture, most of the initial TILs expanded further in number $(2,053 \pm 290$ fold; Supplementary Table 3). Since it is T cells that are mainly responsible for tumor cell control [24, 25], we assessed the proportion of T cells in TILs by fluorescenceactivated cell sorting (FACS) before and after culture (see Supplementary Figure 1 for gating strategy). The proportion of $\mathrm{CD}^{+} \mathrm{T}$ cells was markedly increased after culturing fresh TILs (directly derived from the tumor tissues, $49.7 \% \pm 27.6 \%)$ for 2 -weeks $(81.5 \% \pm 12.8 \%)$ and REP $(91.6 \% \pm 6.9 \%$; Figure $3 \mathrm{~A}$ and $3 \mathrm{~B})$. However, the proportion of other major immune cells such as B cells and myeloid cells (except the proportion of natural killer cells, which increased slightly during the initial 2 weeks' culture, but decreased later) drastically decreased after the ex vivo culture (Supplementary Figure 2). The proportion of $\mathrm{CD}^{+} \mathrm{T}$ cells among $\mathrm{CD}^{+}$TILs was also increased after the REP (fresh $(39.0 \% \pm 14.3 \%$ ), after 2 weeks' culture $(41.5 \% \pm 20.6 \%)$, and post-REP $(60.8 \% \pm 24.7 \%)$; Figure $3 \mathrm{~A}$ and $3 \mathrm{~B})$. For ACT to be effective, tumor-reactive memory $T$ cells should be present in the expanded TILs. Thus, the proportion of $\mathrm{T}$ cells expressing CD45RO (broadly defined as a memory $\mathrm{T}$ cell marker) $[26,27]$ in fresh and cultured TILs was assessed (see Supplementary Figure 1 for gating strategy). The majority ( $\geq 79.0 \%)$ of $\mathrm{T}$ cells were $\mathrm{CD} 45 \mathrm{RO}^{+}$memory $\mathrm{T}$ cells, regardless of the ex vivo cultures, indicating that memory $\mathrm{T}$ cells present in the tissues readily expanded ex vivo (Figure 3C and 3D).

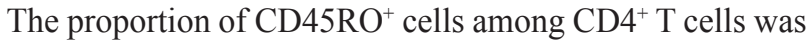
not significantly changed after ex vivo culture (fresh TILs $(88.5 \% \pm 9.0 \%)$, after 2 weeks' culture $(88.9 \% \pm 7.8 \%)$, and post-REP $(85.7 \% \pm 14.3 \%))$, while the proportion of $\mathrm{CD}^{2} 5 \mathrm{RO}^{+}$cells among $\mathrm{CD}^{+} \mathrm{T}$ cells slightly increased in post-REP TILs (fresh TILs $(79.1 \% \pm 12.4 \%$ ), after 2 weeks' culture $(81.9 \% \pm 14.0 \%)$, and post-REP $(90.8 \% \pm$ $6.9 \%$ ); Figure $3 \mathrm{C}$ and $3 \mathrm{D}$ ).

\section{Central memory phenotype $T$ cells -in cancer tissues are readily expanded after TIL culture}

Since expansion of broadly defined memory phenotype T cells in cultured TILs was observed, we then analyzed the composition of memory $\mathrm{T}$ cell subsets in fresh, initial 2 week cultured, and post-REP TILs by FACS (see Supplementary Figure 3 for gating strategy). The majority of the $\mathrm{CD}^{+}$and $\mathrm{CD}^{+} \mathrm{T}$ cells were effector memory $\mathrm{T}$ cells

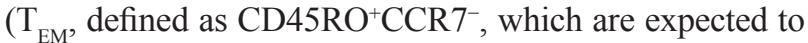
be short-lived in vivo) among the fresh TILs $(83.0 \% \pm 7.8 \%$ for $\mathrm{CD}^{+} \mathrm{T}$ cells; $73.5 \% \pm 12.5 \%$ for $\mathrm{CD}^{+} \mathrm{T}$ cells), the initial 2 week cultured TILs $\left(71.2 \% \pm 13.4 \%\right.$ for $\mathrm{CD}^{+} \mathrm{T}$ cells; $62.9 \% \pm 16.5 \%$ for $\mathrm{CD}^{+} \mathrm{T}$ cells), and the post-REP TILs $\left(66.9 \% \pm 15.5 \%\right.$ for CD4 ${ }^{+} \mathrm{T}$ cells; $71.7 \% \pm 12.9 \%$ for $\mathrm{CD}^{+} \mathrm{T}$ cells; Figure 4) $[26,27]$. Memory stem T cells $\left(\mathrm{T}_{\mathrm{SCM}}\right.$, defined as $\left.\mathrm{CD} 45 \mathrm{RO}^{-} \mathrm{CCR} 7^{+} \mathrm{CD} 62 \mathrm{~L}^{+} \mathrm{CD}^{+} 5^{+}\right)$were mostly absent in the fresh TILs $\left(0.1 \% \pm 0.3 \%\right.$ for $\mathrm{CD}^{+} \mathrm{T}$ cells; $0.3 \% \pm 0.7 \%$ for $\mathrm{CD}^{+} \mathrm{T}$ cells) as well as in the initial 2 week cultured TILs $\left(0.1 \% \pm 0.3 \%\right.$ for $\mathrm{CD}^{+} \mathrm{T}$ cells; $0.4 \%$ $\pm 1.0 \%$ for $\mathrm{CD}^{+} \mathrm{T}$ cells $)$ and post-REP TILs $(0.4 \% \pm 0.7 \%$ for $\mathrm{CD}^{+} \mathrm{T}$ cells; $0.2 \% \pm 0.4 \%$ for $\mathrm{CD}^{+} \mathrm{T}$ cells; Figure 4$)$. The proportion of central memory $\mathrm{T}$ cells $\left(\mathrm{T}_{\mathrm{CM}}\right.$, defined as $\left.\mathrm{CD}^{2} \mathrm{RO}^{+} \mathrm{CCR}^{+}\right)$was relatively low in fresh TILs $(5.1 \%$ $\pm 4.7 \%$ for $\mathrm{CD}^{+} \mathrm{T}$ cells; $3.8 \% \pm 4.5 \%$ for $\mathrm{CD}^{+} \mathrm{T}$ cells $)$, increased after the initial 2 week culture $(19.9 \% \pm 11.6 \%$ for $\mathrm{CD}^{+} \mathrm{T}$ cells; $17.9 \% \pm 10.4 \%$ for $\mathrm{CD}^{+} \mathrm{T}$ cells), and did not change significantly during the REP $(18.2 \% \pm 12.0 \%$ for $\mathrm{CD}^{+} \mathrm{T}$ cells; $19.8 \% \pm 12.0 \%$ for $\mathrm{CD}^{+} \mathrm{T}$ cells; Figure 4$)$. These results indicate that long-term TIL culture under the current conditions is possible without losing the potentially long-living $\mathrm{T}_{\mathrm{CM}}$.

\section{TILs obtained after the REP are functional in vitro}

To determine if the post-REP TILs are potentially functional, we performed in vitro stimulation with phorbol myristate acetate (PMA) and ionomycin (ION), followed by assessment of interferon- $\gamma$ (IFN $\gamma$ ) production on 15 randomly selected post-REP TILs that either had accompanying autologous primary tumor cells or patientderived xenograft (PDX) mice implanted with autologous primary tumor tissues. All the TILs tested produced IFN $\gamma$ at a considerable level $(>2,000 \mathrm{pg} / \mathrm{mL})$ upon stimulation, indicating that post-REP TILs retain functional activity (Figure 5A). To determine the reactivity of post-REP TILs towards the primary tumor, the TILs were cocultured with available autologous primary tumor cells and IFN $\gamma$ production was determined by ELISA. IFN $\gamma$ production from $4 / 6$ post-REP TIL samples was increased in the presence of autologous tumor cells (Figure 5B). Furthermore, increased IFN $\gamma$ production from postREP TILs against autologous primary tumor cells was decreased by addition of anti-MHC I blocking antibody but not by addition of anti-MHC II blocking antibody 
(Supplementary Figure 4), indicating that the response of the TILs to autologous tumor cells is MHC I-restricted, but not MHC II-restricted. Consistently, all autologous tumor cells eliciting TIL reactivity expressed MHC I on the cell surface, while those tumors against which TILs were unreactive did not (Supplementary Figure 5). Furthermore, the expression of MHC II on the tumor cell surface was minor, if expressed (Supplementary Figure 5) and both tumor-reactive post-REP TILs and -non-reactive post-REP TILs showed similar cell composition (almost all T cells in both; Supplementary Figure 6). Therefore, as expected, self-MHC I recognition by post-REP T cells seems to be the most important parameter determining TIL reactivity to tumor cells. This result suggests that ACT would be possible for patients with in vitro tumor-reactive TILs but that not all patients could benefit from ACT.

\section{Post-REP TILs can be functional in the PDX mouse model}

To determine if the post-REP TILs with reactivity towards autologous primary tumor cells in vitro can also be effective in vivo, adoptive transfer of tumor-reactive post-REP TILs into PDX mice successfully implanted with autologous primary tumor tissue was performed and the tumor size was measured over time. The autologous tumors in the PDX mice administered with $1.0 \times 10^{7}$ post-REP TILs grew much slower than those in mice not administered with TILs (Figure 6). This result strongly indicates that TILs from breast cancers could be exploited as an ACT source.

\section{DISCUSSION}

In this study, we showed that TILs can be obtained from all the breast cancer subtypes and that information on the TIL percentage and TLS degree in tumor samples is useful for estimating the number of obtainable TILs after an initial 2 week ex vivo culture. In addition, we showed that such expanded and post-REP TILs contained a considerable level of $\mathrm{T}_{\mathrm{CM}}$, that a large proportion of post-REP TIL samples were reactive to autologous tumor cells in vitro, and that these in vitro tumor-reactive post-
A

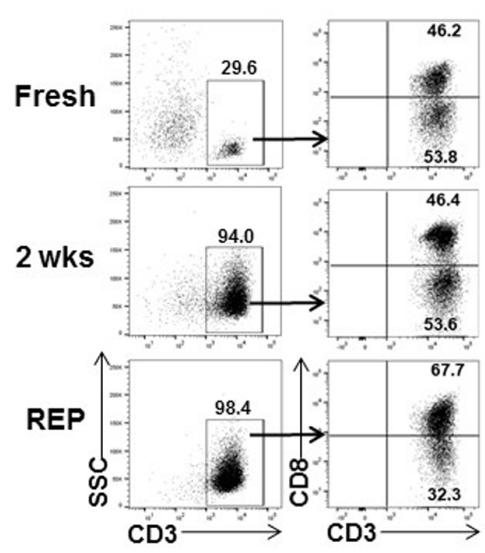

C

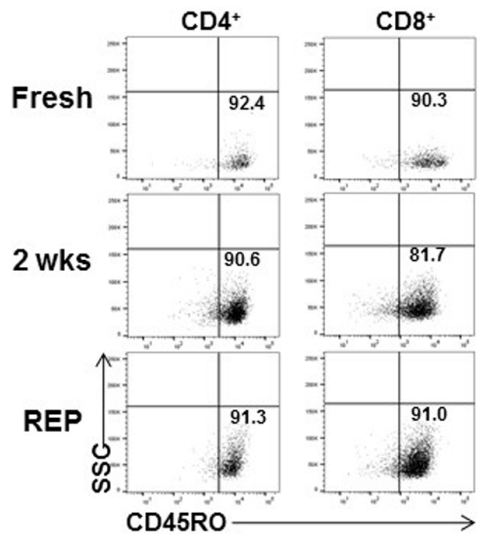

B
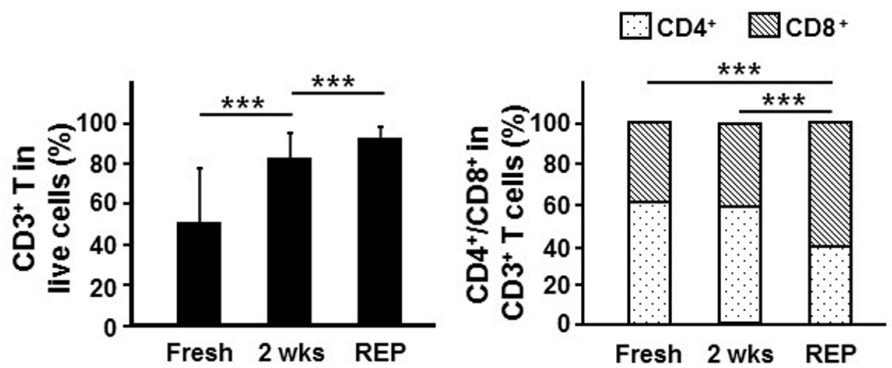

D
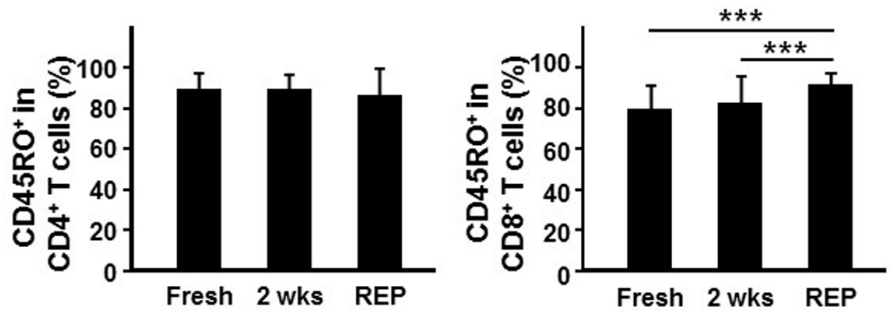

Figure 3: Ex vivo TIL culture enriches memory phenotype $\mathbf{C D 8}^{+} \mathbf{T}$ cells. Analysis of $\mathrm{T}$ cells and their subsets $(\mathrm{A}, \mathbf{B})$, and memory phenotype T cells (C, D) in TILs. Single cells directly derived from fresh breast cancer tissues (fresh, $n=33$ ), TILs obtained after 2 weeks' ex vivo culture of breast cancer tissue fragments ( 2 wks, $n=132)$, and post-REP TILs (REP, $n=45)$ were analyzed by flow cytometry. (A) Representative FACS data showing percentage of T cells (CD3 $\left.{ }^{+}\right)$among live cells, percentage of $\mathrm{CD}^{+} \mathrm{T}^{-}$cells $\left(\mathrm{CD} 3^{+} \mathrm{CD} 8^{-}\right)$ and of $\mathrm{CD}^{+}\left(\mathrm{CD}^{+} \mathrm{CD}^{+}\right) \mathrm{T}$ cells among $\mathrm{T}$ cells, and $(\mathrm{C})$ percentages of memory phenotype $\mathrm{CD} 4^{+} \mathrm{T}$ cells $\left(\mathrm{CD}^{+} \mathrm{CD}^{-} \mathrm{CD} 45 \mathrm{RO}^{+}\right)$and $\mathrm{CD}^{+} \mathrm{T}$ cells $\left(\mathrm{CD}^{+} \mathrm{CD}^{+} \mathrm{CD} 45 \mathrm{RO}^{+}\right)$among $\mathrm{CD} 4^{+} \mathrm{T}$ cells $\left(\mathrm{CD} 3^{+} \mathrm{CD} 8^{-}\right)$and $\mathrm{CD} 8^{+} \mathrm{T}$ cells $\left(\mathrm{CD} 3^{+} \mathrm{CD} 8^{+}\right)$, respectively. $(\mathrm{B}, \mathrm{D}) \mathrm{FACS}$ results expressed as the mean \pm SD summarized as histograms. Kruskal-Wallis test and Mann-Whitney $U$-test were employed for statistical analysis. ${ }^{* * *} p<0.001$. 
REP TILs could function in an in vivo PDX model. To the best of our knowledge, this is the largest study describing successful ex vivo expansion of TILs and evaluating their potential as an ACT source in breast cancer.

Successful TIL expansion from several cancer types has been reported, including melanoma, colorectal cancer, renal cell carcinoma, and pancreatic cancer [20, 25, 28, 29]. Regarding breast cancer, a few reports have described initial TIL cultures; however, the case numbers in these studies were small $(<20)$, and reactivity of TILs to autologous tumors and the proportion with memory $\mathrm{T}$ cell phenotype, critical parameters for predicting therapeutic efficacy, were not described, making it difficult to ascertain the utility of ACT $[16,24]$. In this study, we successfully expanded a large number of TILs (from more than 100 cancer samples), which were potentially usable for ACT in a clinical setting after a standard REP was performed. We consider the essential TIL number after the initial 2 week culture to be $\geq 1.0 \times 10^{7}$ cells, which, combined with the over 1,000-fold expansion of TILs possible under a
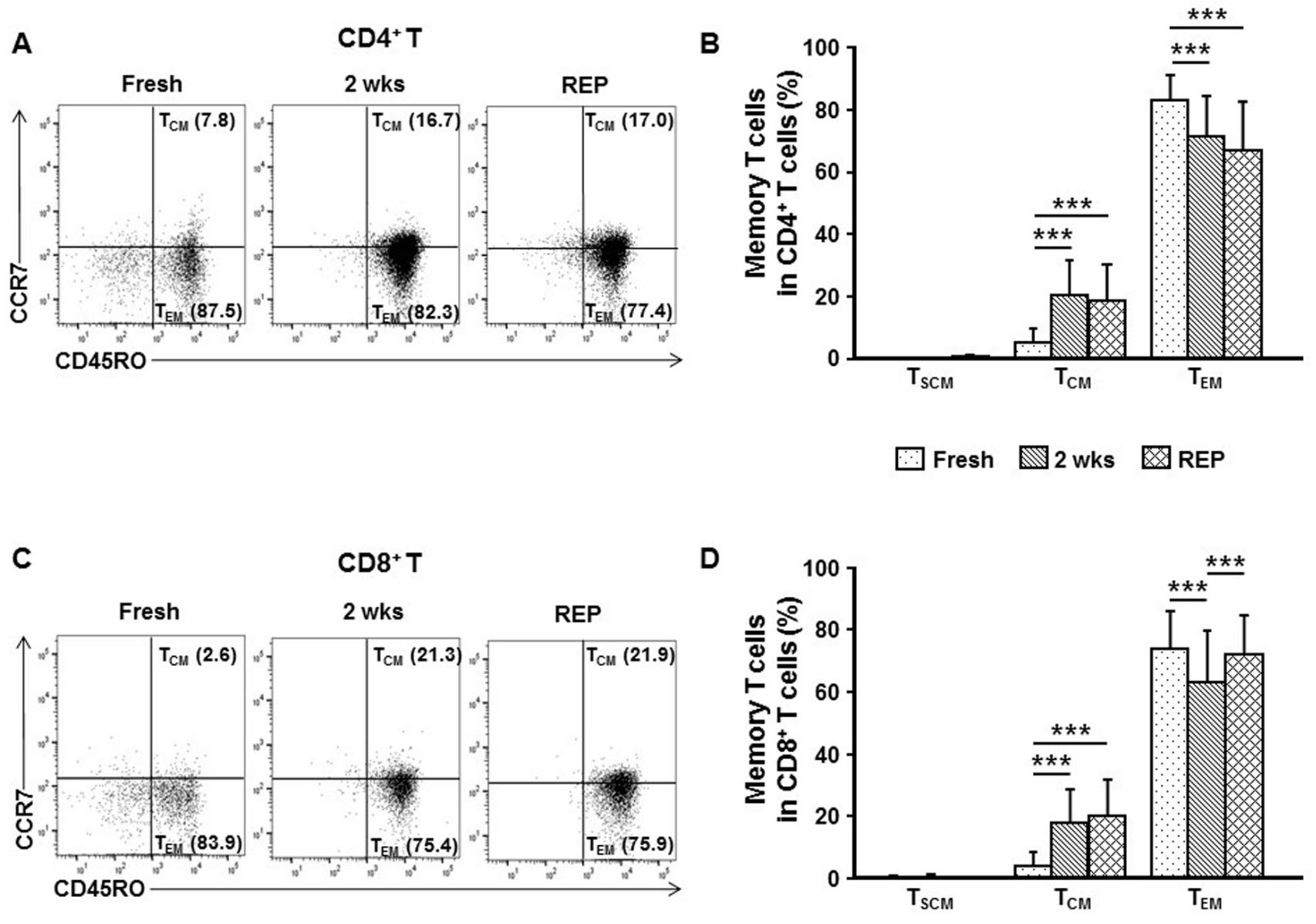

Figure 4: Ex vivo TIL culture does not compromise the proportion of the central memory phenotype T cell subset. Memory $\mathrm{CD}^{+}(\mathbf{A}, \mathbf{B})$ and $\mathrm{CD}^{+}(\mathbf{C}, \mathbf{D}) \mathrm{T}$ cell subpopulations among single cells directly derived from fresh breast cancer tissue (fresh, $n=33)$, those among TILs obtained after the 2 week ex vivo culture of breast cancer tissue fragments $(2$ wks, $n=132)$, and those among post-REP TILs (REP, $n=45$ ) were analyzed by flow cytometry. Representative FACS data showing percentage of memory stem T cells $\left(\mathrm{T}_{\mathrm{SCM}}, \mathrm{CD} 45 \mathrm{RO}^{-} \mathrm{CCR} 7^{+} \mathrm{CD} 62 \mathrm{~L}^{+} \mathrm{CD} 95^{+}\right)$, central memory phenotype $\mathrm{T}$ cells $\left(\mathrm{T}_{\mathrm{CM}}, \mathrm{CD} 45 \mathrm{RO}^{+} \mathrm{CCR} 7^{+}\right)$, or effector memory $\mathrm{T}$ cells $\left(\mathrm{T}_{\mathrm{EM}}\right.$, $\mathrm{CD}^{2} 5 \mathrm{RO}^{+} \mathrm{CCR}^{-}$) among $\mathrm{CD}^{+}(\mathrm{A})$ and $\mathrm{CD}^{+}(\mathrm{C}) \mathrm{T}$ cells. (B, D) FACS results expressed as the mean $\pm \mathrm{SD}$ summarized as histograms. Kruskal-Wallis test and Mann-Whitney $U$-test were employed for the statistical analysis. ${ }^{* * *} p<0.001$. 
tumor fragment (Supplementary Table 2), the majority of these cases $(20 / 32,62.5 \%)$ had too few fragments to expand TILs to the clinically sufficient $>1 \times 10^{7}$ cells, indicating that tumor tissues $<4 \mathrm{~mm}$ in diameter would be impractical for use in ACT. In cases of samples that yielded $<1.0 \times 10^{7}$ cells after the initial 2 week culture, a more extended initial TIL culture period may help increase cell number. Indeed, in some reports, TILs were initially cultured for 4 weeks to obtain at least $3 \times 10^{7}$ cells from melanoma tissue fragments [21]. Thus, with this possibility in mind, the success rate of obtaining a sufficient number of TILs after ex vivo culture is likely to be much higher than that obtained in this study, and considering that the proportion of $\mathrm{T}_{\mathrm{CM}}$ did not decrease significantly after initial TIL and REP cultures, longercultured cells are likely to be capable of surviving in vivo and functioning similarly to shorter-cultured cells. Furthermore, since the ex vivo expansion of TILs from TNBC sample was recently reported to be enhanced in the presence of 4-1BB agonistic antibody (against CD137, a TNF receptor superfamily member 9), it is possible that this approach could enhance TIL expansion from other breast tumor types [31].

It would be very useful for planning ACT if routine histological analysis, performed on tumor tissues by pathologists, could give good information about the number of TILs likely to be expanded ex vivo. Therefore, in the present study, the number of TILs obtained after the initial 2 week culture was analyzed together with tissue parameters related to TIL number such as the percentage of TILs and the degree of TLS observed in the tissue sections. As expected, predominantly, the samples with a

A
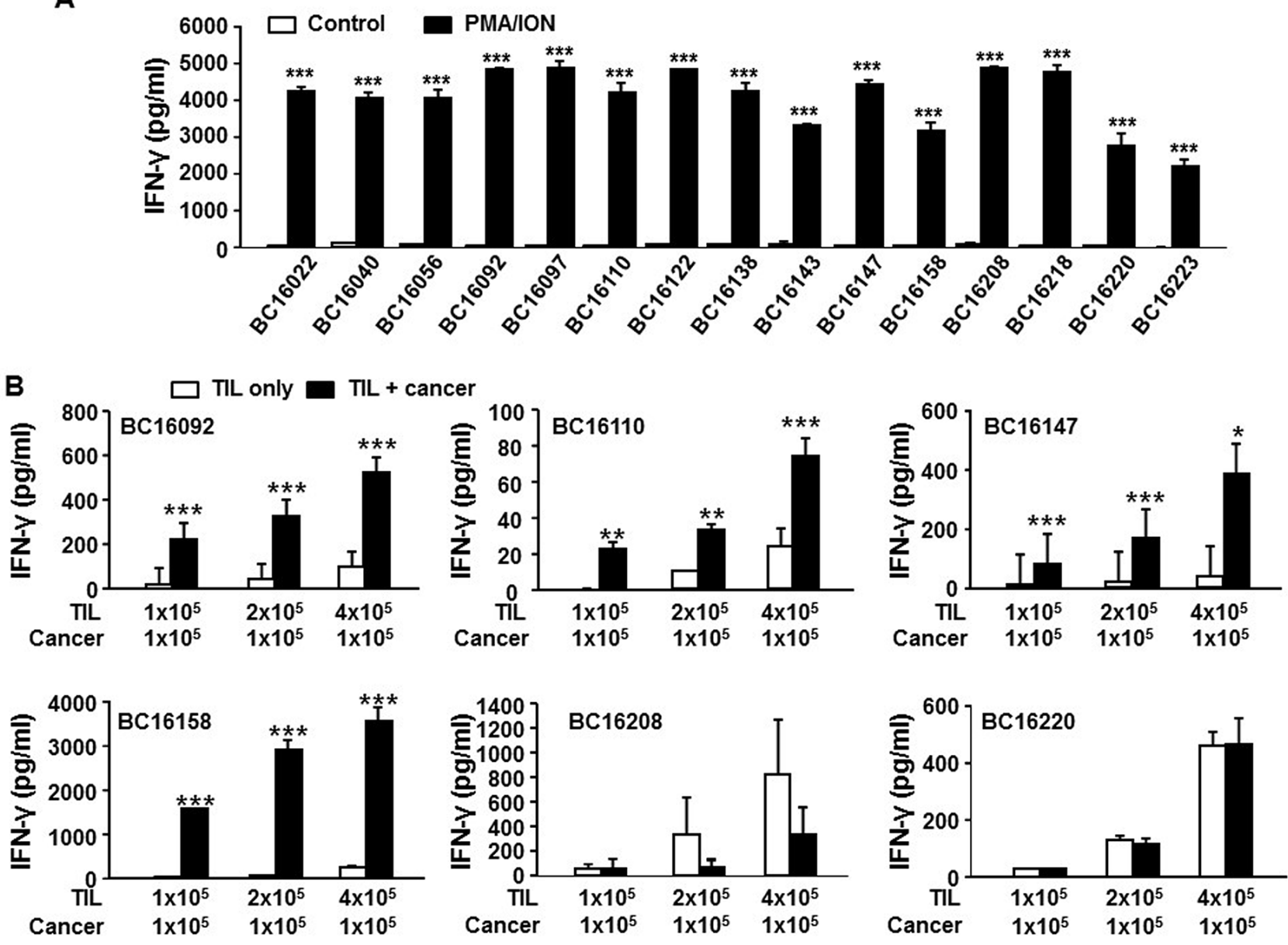

Figure 5: Post-REP TILs are functional and retain reactivity towards autologous primary tumor cells cultured in vitro. Two week cultured TILs were further expanded for 2 weeks under a standard REP condition and tested for functional activity in vitro. (A) PMA/ION response: $1 \times 10^{5}$ post-REP TILs (from each of 15 randomly selected samples; sample IDs are shown) were seeded in 96-well plates and treated with or without PMA $(32.4 \mathrm{nM}) / \mathrm{ION}(1 \mu \mathrm{g} / \mathrm{ml})$. After $24 \mathrm{~h}$, cell culture supernatants were collected and the IFN $\gamma$ level was measured by ELISA ( $n=3$ or 4 per group). Open bars indicate no treatment (control), and filled bars indicate PMA/ION treatment (PMA/ION). (B) The reactivity of TILs to autologous primary cancer cells. Post-REP TILs from six selected samples were cocultured with (filled bar) or without (open bar) the autologous primary tumor cells $\left(1 \times 10^{5}\right)$ at an effector:target cell ratio of 1:1, 2:1, or 4:1. After $24 \mathrm{~h}$, cell culture supernatants were collected and the IFN $\gamma$ level was measured by ELISA ( $n=3$ or 4 per group). A non-paired Student's $t$-test was performed. ${ }^{*} p<0.05,{ }^{* *} p<0.01,{ }^{* * *} p<0.001$. 
higher percentage of TILs observed in the tissue yielded more cultured TILs. Interestingly, when we considered TIL percentage and TLS level together in the same tissue sample, even samples with a low percentage of TILs inside the invasive tumor border could yield sufficient numbers of expanded TILs if they contained abundant TLSs beyond the invasive tumor margin. This result shows that TLSs from solid tumors contribute significantly to the number of TILs obtained after ex vivo expansion of TILs. In addition, this indicates that histological analysis for assessing TIL percentage and TLS degree in tumor tissues could provide useful information for designing an ACT plan.

As expected, in this study, ex vivo TIL culture enriched T cells. Among T cells, the proportions of $\mathrm{CD}^{+}$ and $\mathrm{CD}^{+} \mathrm{T}$ cells were comparable in fresh TILs and in the initial 2 week cultured TILs, and the proportion of $\mathrm{CD}^{+} \mathrm{T}$ cells increased after the REP culture. Since the major anti-cancer effector T cells are known to be $\mathrm{CD} 8^{+}$ $\mathrm{T}$ cells $[31,32]$, and in the present study we found $\mathrm{CD} 8^{+}$ $\mathrm{T}$ cells to account for a major portion $(\sim 60 \%)$ of the post-REP TILs, we speculate that $\mathrm{CD}^{+} \mathrm{T}$ cells would have played a major role in mediating the anti-tumor reactivity we observed in vitro and in vivo after ACT in the PDX model. However, since $\mathrm{CD}^{+} \mathrm{T}$ cells were also present as a considerable fraction $(\sim 40 \%)$ in the post-REP $\mathrm{T}$ cells and adoptive transfer of $\mathrm{CD}^{+} \mathrm{T}$ cells is reported to be capable of managing various cancers including cholangiocarcinoma and melanoma successfully $[13,33]$,
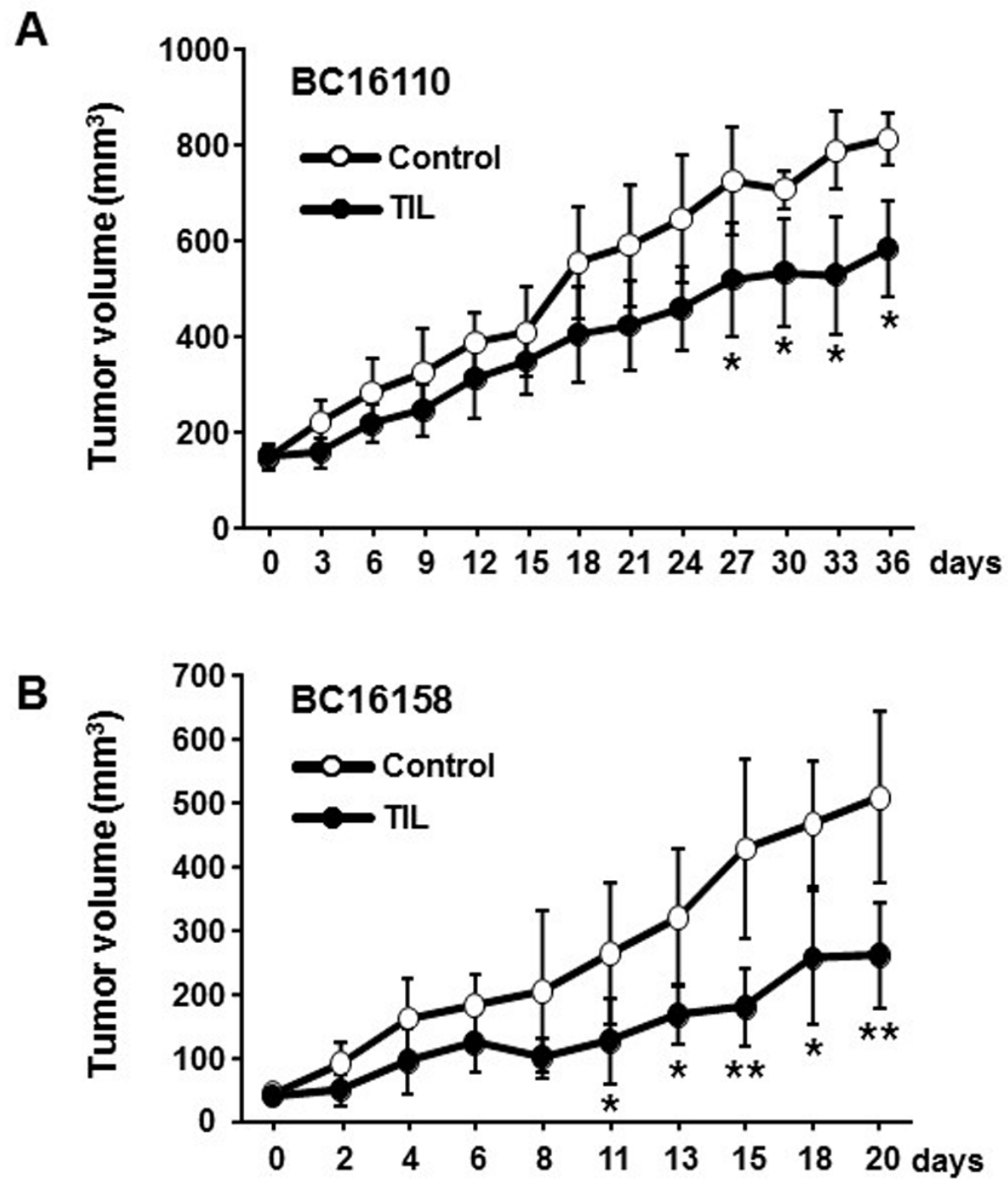

Figure 6: In vitro tumor-reactive post-REP TILs are functional in a PDX mouse model in vivo. PDX mice were created by implanting tumor tissues derived from each of two patient samples (from a lymph node with metastatic breast cancer, sample BC16110 (A), and from breast, sample BC16158 (B)). When tumors in the PDX mice were palpable, $1 \times 10^{7}$ post-REP TILs (TIL group, $n=4$ for $\mathrm{BC} 16110$ and $n=5$ for $\mathrm{BC} 16158$ ) or PBS (control group, $n=4$ for $\mathrm{BC} 16110$ and $n=5$ for $\mathrm{BC} 16158$ ) was administered into the tail vein, and IL-2 (200,000 IU/mice) and IL-15 (1 $\mathrm{g} /$ mice) were administered simultaneously into the peritoneal cavity of the mice in both groups. Then, IL-2 (200,000 IU/mice) was administered for the following 2 days (total of three times) and IL-15 (1 $\mu \mathrm{g} / \mathrm{mice}) \mathrm{was}$ administered every other day for 8 days (total of five times). After administration of TILs (day 0), tumor size was measured using calipers. Tumor volumes were calculated using the formula $1 / 2 \times$ length $\times(\text { width })^{2}$ and expressed as the mean $\pm \mathrm{SD}$. A non-paired Student's $t$-test was performed. ${ }^{*} p<0.05,{ }^{* *} p<0.01$. 
we cannot exclude a significant contribution by the $\mathrm{CD} 4^{+}$ $\mathrm{T}$ cells to the anti-tumor immune response. For ACT to be effective, memory $\mathrm{T}$ cells with an extended viability are considered to be critical [27]. Indeed, existence of memory $\mathrm{T}$ cell subsets with prolonged viability in ex vivo expanded TILs has been shown to be important for therapeutic efficacy in mouse and human studies [27, 34, $35]$. In the current study on breast cancer, we observed that the proportion of $\mathrm{T}_{\mathrm{CM}}$ did not decline significantly during ex vivo TIL cultures, and the proportion even increased after the initiation of ex vivo culture. In addition, the proportion of $\mathrm{T}_{\mathrm{CM}}$ was not low (about 20\%) after TIL culture. These results together suggest that $\mathrm{T}_{\mathrm{CM}}$ would play a major role in tumor control in adoptive TIL therapy applied in breast cancer. The preferential increase of the $\mathrm{T}_{\mathrm{CM}}$ population after the initiation of ex vivo TIL culture could be caused by the liberation from the suppression of $\mathrm{T}_{\mathrm{CM}}$ proliferation/survival/differentiation induced by the immunosuppressive tumor environment $[36,37]$. TGF- $\beta$ is likely to be one of the main factors responsible for this suppressive environment, as it can inhibit clonal expansion of memory $\mathrm{CD}^{+} \mathrm{T}$ cells and inhibit $\mathrm{T}_{\mathrm{CM}}$ differentiation $[36,38]$.

All the post-REP TILs tested showed a good response to PMA/ION, indicating that TILs are functionally active after ex vivo culture. However, not all the TIL samples co-cultured with autologous primary tumor cells were reactive to the tumor cells. These results indicate that TILs from certain samples cannot recognize the autologous tumor. We presume that one of the main reasons for the unresponsiveness of TILs to certain autologous tumors is downregulation of MHC I molecules on the tumor cells, known to occur in some cancers [39], because we observed that TILs responded well to autologous, cultured primary tumor cells expressing MHC I on the cell surface but not to those without MHC I (Supplementary Figures 4 and 5). When post-REP TILs reactive to autologous tumors in vitro were administered to PDX mice bearing autologous primary tumor tissues, the tumor growth was retarded. Although, because of a low PDX implantation rate, we could test this in only two cases (one bearing breast-derived, the other metastatic lymph node tumor tissue), we obtained reasonable positive responses from both cases. Therefore, TILs reactive to autologous tumors in vitro were apparently effective in vivo as well. Taken together, these results strongly suggest that ACT of post-REP TILs into patients with breast cancer could benefit those patients whose TILs show good reactivity to autologous tumor cells in vitro.

Among the cancer samples analyzed, we included samples derived from patients treated systemically with neoadjuvants. Although these neoadjuvant-treated samples yielded a slightly smaller number of TILs after ex vivo culture, the basic features, such as memory phenotype and expansion levels, were not different from those of samples from patients not treated with neoadjuvants.
Since patients containing residual tumors after systemic neoadjuvant therapy, especially those with TNBC, are prone to cancer recurrence after the therapy, such highrisk patients might benefit from adoptive TIL transfer [40]. In addition, because we were able to culture a comparable number of TILs $\left(>1.0 \times 10^{5}\right.$ TILs $)$ from metastatic sites of breast cancer (Supplementary Table 2 and data not shown), patients with distant metastasis could particularly benefit from ACT with ex vivo expanded TILs.

In this study, we successfully expanded TILs from over 100 breast cancer samples including all the breast cancer subtypes and showed that the ex vivo expanded TILs contained a significant proportion of $\mathrm{T}_{\mathrm{CM}}$ cells and a large proportion of TIL samples were reactive to autologous tumors. Together, these results indicate that ACT using ex vivo expanded TILs is feasible in breast cancer. Thus, in the future, ACT of TILs derived from breast cancers could become a good treatment alternative for certain patients with a severe disease burden.

\section{MATERIALS AND METHODS}

\section{Patients and histological evaluation of breast cancer tissues}

Breast cancer tissue obtained during surgery with or without neoadjuvant systemic chemotherapy was collected from 198 female patients after obtaining informed consent before surgery in 2016. All breast cancer tissue was derived from the breast except two cases from lymph nodes with metastasis (Supplementary Tables 1 and 2). This study was approved by the Institutional Review Board of Asan Medical Center (IRB\#2015-0438).

The H\&E-stained slides were reviewed by two pathologists (H.J.L. and G.G.), and the percentage of TILs was determined. Percentage of TILs was defined as the mean percentage of the stroma with invasive carcinoma infiltrated by lymphocytes and plasma cells. Presence of TILs was estimated in $10 \%$ increments, or if less than $10 \%$ of the stroma was infiltrated, as $1 \%, 2 \%$, or $5 \%$ [ 41 , 42]. The degree of TLS in tumor-adjacent tissue (scored as 0 where there was none; scored as 1 (little) where a TLS occupied an area $<10 \%$ of the circumference of the tumor; scored as 2 (moderate) when $10-50 \%$; or scored as 3 (abundant) when $>50 \%$ ) [43], histological subtype and grade, tumor size, $\mathrm{pT}$ stage, $\mathrm{pN}$ stage (or ypT and ypN), and lymphovascular invasion were also recorded. All available full sections were evaluated. For subtyping, cancer tissues were stained immunohistochemically with antibodies against ER (diluted 1:200; NCL-L-ER-6F11, Novocastra, Newcastle-upon-Tyne, UK), PR (diluted 1:200; NCL-L-PGR-312, Novocastra), and HER2 (diluted 1:8; 88-4422, Ventana Medical Systems, Tucson, AZ, USA). ER and PR levels were regarded as positive if there was at least $1 \%$ tumor nuclei staining [44]. $\mathrm{HR}^{+}$ tumors were defined as those with positive ER and/or 
PR staining. HER2-overexpressing tumors were defined as those with scores of $3+$ by immunohistochemistry or by gene amplification by silver in situ hybridization [45]. Lymphoid aggregation with vessels showing features of high endothelial venules (plump, cuboidal endothelial cells) with or without germinal centers was considered as TLS. Histological type was defined based on the 2012 WHO classification criteria, and histological grade was assessed using the modified Bloom-Richardson classification [46].

\section{Isolation and ex vivo expansion of TILs}

Breast cancer tissue was placed in RPMI 1640 medium and brought to the laboratory within $2 \mathrm{~h}$ of surgery. After washing with phosphate-buffered saline (PBS; pH 7.4) containing $1 \times$ ZellShield anticontaminant agent (Minerva Biolabs, Berlin, Gerrmany), the tumor tissues were minced into 1-mm-diameter pieces. The minced fragments were plated into a 24-well plate (four fragments/well) containing $2 \mathrm{~mL}$ of TIL culture medium (RPMI 1640 medium supplemented with 10\% fetal bovine serum $(\mathrm{FBS}), 1 \times$ ZellShield, $1 \times 2$-mercaptoethanol, and 1,000 IU/mL IL-2 (Miltenyi Biotec, Auburn, CA, USA)). Plates were incubated at $37^{\circ} \mathrm{C}$ for 14 days to allow TILs to extravasate from the tissue fragment and expand. Half of the medium was changed every 2 days, and the cells were expanded into additional wells when the medium turned yellow. After 14 days, TILs were recovered by centrifugation at $1,500 \mathrm{rpm}$ for $5 \mathrm{~min}$ after passing the mixture of tissue fragments and TIL through a $40-\mu \mathrm{m}$-pore nylon mesh strainer, as described previously [23, 27]. TILs were then counted and cryopreserved.

For further rapid expansion of TILs, the standard REP was employed as previously described [29], with a minor change as follows: $5 \times 10^{4}$ TILs were cultured at $37^{\circ} \mathrm{C}$ in a T25 flask containing $3 \mathrm{~mL}$ of $50 \%$ RPMI 1640 and $50 \%$ AIM-V media supplemented with $10 \%$ FBS, $1 \times$ ZellShield, and 1,000 IU/mL IL-2 as well as $30 \mathrm{ng} / \mathrm{mL}$ human anti-CD3 antibody (OKT3, Miltenyi Biotec) and $1 \times 10^{7}$ irradiated (50 Gy) allogeneic peripheral blood mononuclear cell feeders. On day $4,3 \mathrm{~mL}$ of the same media was added to the flask, and then $3 \mathrm{~mL}$ of media was added every 2 days. After 14 days, TILs (post-REP TILs) were collected, counted, and cryopreserved.

\section{Preparation of fresh TILs directly from tumor tissue and culturing primary cancer cells}

The minced breast cancer tissue was incubated for $1 \mathrm{~h}$ in digestion buffer (DMEM-F12, 2\% FBS, 1\% penicillin/streptomycin, $10 \mu \mathrm{g} / \mathrm{mL}$ insulin, and $10 \mathrm{ng} / \mathrm{mL}$ epidermal growth factor) supplemented with $1 \times$ collagenase/hyaluronidase (Gendepot, Barker, TX, USA). The digested samples were centrifuged at $80 \mathrm{~g}$ for $30 \mathrm{~s}$, and the supernatant was passed through a $70-\mu \mathrm{m}-$ pore nylon mesh strainer; the cells passing through were collected as one component of fresh TILs. The pellet from the digested samples was resuspended in $0.25 \%$ trypsin/ EDTA and incubated for 3-5 min to release single cells. Once a single cell suspension was obtained, cold Hank's balanced salt solution containing 2\% FBS was added, and cells were recovered by centrifugation at $300 \mathrm{~g}$ for $5 \mathrm{~min}$. The cells from the supernatants and the single cells from the pellet were combined to become the total fresh TILs from tumor tissue, counted, and cryopreserved. For the culture of primary cancer cells, only the single cells from the pellet were used.

To establish primary breast cancer cell cultures, the dissociated breast cancer cells were cultured on $100 \mathrm{~mm}$ collagen I-coated plates (Corning, Corning, NY, USA) at $37^{\circ} \mathrm{C}$ as previously described [47] in DMEM/F12 medium containing $2 \% \mathrm{FBS}, 5 \mathrm{ng} / \mathrm{mL}$ epidermal growth factor (Invitrogen, Carlsbad, CA, USA), $0.3 \mu \mathrm{g} / \mathrm{mL}$ hydrocortisone (Sigma-Aldrich, St. Louis, MO, USA), $0.5 \mathrm{ng} / \mathrm{mL}$ cholera toxin (Sigma-Aldrich), $5 \mathrm{nM} \mathrm{3,3',5-triiodo-L-}$ thyronine (Sigma-Aldrich), $0.5 \mathrm{nM} \beta$-estradiol (SigmaAldrich), $5 \mu \mathrm{M}$ isoproterenol hydrochloride (SigmaAldrich), $50 \mathrm{nM}$ ethanolamine (Sigma-Aldrich), $50 \mathrm{nM}$ O-phosphorylethanolamine (Sigma-Aldrich), 1× insulin/ transferrin/selenium (Invitrogen), and 1\% penicillin/ streptomycin until confluent, and sub-cultured at least twice before cryopreservation.

\section{Derivation of PDX mouse model}

The protocols for this study were approved by the International Animal Care and Use Committee of the Laboratory of Animal Research at the Asan Medical Center, Seoul, Republic of Korea. To derive a PDX mouse model implanted with tumor tissues, four tumor fragments $\left(4 \mathrm{~mm}^{3}\right.$ each) from each tumor sample were implanted into an inguinal mammary fat pad of 4-6-weekold immunodeficient female NOD.CB17-Prkdc sid (NOD$S C I D$, obtained from Koatech Inc., Seoul, Korea) or NOD.Cg-Prkdcscid Il2rgtm $1 \mathrm{Wjl} / \mathrm{SzJ}$ (NSG, obtained from Jackson Laboratory, Bar Harbor, ME, USA) mice [5]. For stimulating the growth of breast cancer in the PDX mouse, an estradiol pellet (Innovative Research of America, Sarasota, FL, USA) was also implanted under the skin of the upper back, as previously described [5]. Body weight and tumor growth were monitored once a week. When tumors grew up to $1 \mathrm{~cm}$ in diameter, they were excised and some fragments were cryopreserved for future analysis, while other fragments were re-transplanted to NOD.CB17Prkdc $c^{\text {scid }}$ mice for functional assays. Tumor tissues of PDX mice were immunostained for cancer subtyping, and in all cases they showed the same subtypes as those of the implanted human cancer tissue.

\section{Flow cytometry analysis of stained single cells}

To analyze TIL composition, T cell subsets and their memory phenotypes, single cells dissociated from 
tumor tissues (fresh TILs), 2 week cultured TILs, and post-REP TILs were stained for surface marker expression as previously described [48]. Briefly, the prepared single cells were first Fc blocked with human BD Fc block (BD Biosciences, San Diego, CA, USA) in ice-cold FACS buffer (PBS containing 2\% FBS) for $20 \mathrm{~min}$ and then surface-stained at $4^{\circ} \mathrm{C}$ in the dark for $30 \mathrm{~min}$ with the following antibodies: PE-Cy7-labeled anti-CD3 (OKT3; BioLegend, San Diego, CA, USA), APC-Cy7-labeled anti-CD8 (HIT8a; BioLegend), FITC-labeled anti-CCR7 (3D12; BD Biosciences), APC-labeled anti-CD45RO (UCHL1; BioLegend), PerCP-Cy5.5-labeled anti-CD62L (DREG-56; BioLegend), FITC- and PE-labeled anti-CD45 (HI30; BioLegend), Pacific blue-labeled anti-CD95 (DX2; BioLegend), PE-labeled CD11b (ICRF44; BioLegend), APC-labeled CD19 (HIB19; BioLegend), and Pacific blue-labeled CD56 (HCD56; BioLegend). To evaluate the expression of MHC I or II on the surface of primary cancer cells, single cells were similarly surface-stained with Pacific blue-labeled anti-MHC I (W6/32; BioLegend) and Alexa fluor 647-labeled anti-MHC II (Tu39; BioLegend). After washing with FACS buffer, cells were fixed with $2 \%$ paraformaldehyde, permeabilized with $90 \%$ methanol, and stained at $4^{\circ} \mathrm{C}$ in the dark for 30 min with FITClabeled anti-cytokeratins (CKs) 7, 8, 18, and 19 (CK36H5; Miltenyi Biotec) and PE-Cy7-labeled anti-EpCAM (9c4; BioLegend). Cancer cells are identified as $\mathrm{CK}^{+}$or $\mathrm{EpCAM}^{+}$cells $[47,49]$. The stained cells were assessed using a FACSCanto II (BD Biosciences) and analyzed using FlowJo software (Tree Star, Ashland, OR, USA).

\section{In vitro functional test of TILs}

To assess the capability of IFN $\gamma$ production by TILs, $1 \times 10^{5}$ post-REP TILs were stimulated with PMA (32.4 $\mathrm{nM}$, Sigma-Aldrich) and ION (1 $\mathrm{g} / \mathrm{mL}$, Sigma-Aldrich) in 96-well plates for $24 \mathrm{~h}$. To examine the reactivity of the TILs against autologous cancer cells, the TILs were co-cultured for $24 \mathrm{~h}$ with $1 \times 10^{5}$ autologous breast cancer cells in 96-well plates at effector:target cell ratios of 1:1, 2:1, and 4:1. To perform MHC I- or MHC II-blocking experiments during the co-culture, autologous cancer cells were treated with anti-MHC I (W6/32, BioLegend, $10 \mu \mathrm{g} / \mathrm{mL}$ ) or anti-MHC II (Tu39, BioLegend, $10 \mu \mathrm{g} / \mathrm{mL}$ ) antibody for $1 \mathrm{~h}$ prior to the co-culture with TILs. After stimulation of TILs with PMA/ION or co-culture, culture supernatants were collected after centrifuging the culture plate at 1,500 rpm for $5 \mathrm{~min}$ to exclude cells and debris. The IFN $\gamma$ level was measured using a human IFN- $\gamma$ ELISA kit (K0331121, Koma Biotech, Seoul, Korea) according to the manufacturer's guidelines.

\section{In vivo functional test of TILs in the PDX mouse model}

When implanted tumors in the PDX mice were palpable, one group of mice received $1 \times 10^{7}$ post-REP
TILs via the tail vein, while the other group received PBS. In addition, to aid engraftment and/or survival of the transferred TILs both groups of mice received intraperitoneal IL-2 (200,000 IU/mice, Miltenyi Biotec) and IL-15 ( $1 \mu \mathrm{g} /$ mice; Peprotech, Rocky Hill, NJ, USA) on the same day (D0). Thereafter, IL-2 (200,000 IU/mice) was administered on the following 2 days (i.e., a total of three times) and IL-15 (1 $\mu \mathrm{g} /$ mice $)$ was administered every other day for 8 days (i.e., a total of five times). Tumor growth was then measured two or three times a week using calipers. Tumor volumes (in $\mathrm{mm}^{3}$ ) were calculated using the formula $1 / 2 \times$ length $\times(\text { width })^{2}$. A minimum of four mice per group was used for each experiment.

\section{Statistical analysis}

All of the statistical analyses were conducted using SPSS statistical software version 20 (SPSSA). The Kruskal-Wallis test, Mann-Whitney $U$-test, and nonpaired Student's $t$-test were used to evaluate the data. All of the tests were two-sided, and $p$ values less than 0.05 were considered significant. Data are shown as the median \pm range or mean \pm standard deviation (SD). Correlations were assessed using Spearman's rank correlation analysis.

\section{Abbreviations}

ACT: adoptive cell transfer; CAR: chimeric antigen receptor; CK: cytokeratin; ER: estrogen receptor; FACS: fluorescence-activated cell sorter; FBS: fetal bovine serum; HER2: human epidermal growth factor receptor 2; HR: hormone receptor; H\&E: hematoxylin and eosin; IFN $\gamma$ : interferon- $\gamma$; ION: ionomycin; NAC: neoadjuvant chemotherapy; PBS: phosphate-buffered saline; PDX: patient-derived xenograft; PMA: phorbol myristate acetate; PR: progesterone receptor; REP: rapid expansion protocol; $\mathrm{SD}$ : standard deviation; $\mathrm{T}_{\mathrm{CM}}$ : central memory $\mathrm{T}$ cells; $\mathrm{T}_{\mathrm{EM}}$ : effector memory T cells; TIL: tumor-infiltrating lymphocyte; TLS: tertiary lymphoid structure; TNBC: triple-negative breast cancer; $\mathrm{T}_{\mathrm{SCM}}$ : memory stem $\mathrm{T}$ cells.

\section{Author contributions}

Conception and design: HJL, MSL, and GG. Development of methodology: HJL, YAK, CKS, SHH, HSP, SYP, WSB, SC, JJ, SYK, and ML. Acquisition of data: YAK, CKS, HIS, HSP, SYP, WSB, SH, JHL, and YSC. Analysis and interpretation of data: HJL, YAK, CKS, SYP, and MSL. Writing, review, and/or revision of the manuscript: HJL, YAK, CKS, MSL, and GG. Providing clinical specimens and intellectual support: HJL, IHS, IAP, ML, JK, and SBL. All authors have read and approved the final manuscript.

\section{CONFLICTS OF INTEREST}

The authors declare no conflicts of interest. 


\section{FUNDING}

This study was supported by the Korean Health Technology R\&D Project, Ministry of Health \& Welfare (HI15C0708); Basic Science Research Programs through the National Research Foundation of Korea (NRF) funded by the Ministry of Science, ICT \& Future Planning, Republic of Korea (NRF-2015R1C1A1A02036484, NRF-2016R1D1A1B03935367, NRF-2014M3A9D5A010 73836, NRF-2017R1A2B4003619); the Asan Institute for Life Sciences, Asan Medical Center, Seoul, Korea (2016732, 2017-169, and 2017-607); and Korean Breast Cancer Foundation.

\section{REFERENCES}

1. DeRose YS, Wang G, Lin YC, Bernard PS, Buys SS, Ebbert MT, Factor R, Matsen C, Milash BA, Nelson E, Neumayer L, Randall RL, Stijleman IJ, et al. Tumor grafts derived from women with breast cancer authentically reflect tumor pathology, growth, metastasis and disease outcomes. Nat Med. 2011; 17:1514-20. https://doi.org/10.1038/nm.2454.

2. McGuire A, Brown JA, Malone C, McLaughlin R, Kerin MJ. Effects of age on the detection and management of breast cancer. Cancers (Basel). 2015; 7:908-29. https://doi. org/10.3390/cancers7020815.

3. Lin SX, Chen J, Mazumdar M, Poirier D, Wang C, Azzi A, Zhou M. Molecular therapy of breast cancer: progress and future directions. Nat Rev Endocrinol. 2010; 6:485-93. https://doi.org/10.1038/nrendo.2010.92.

4. Bense RD, Sotiriou C, Piccart-Gebhart MJ, Haanen JB, van Vugt MA, de Vries EG, Schröder CP, Fehrmann RS. Relevance of Tumor-Infiltrating Immune Cell Composition and Functionality for Disease Outcome in Breast Cancer. J Natl Cancer Inst. 2016; 109:djw192.

5. Whittle JR, Lewis MT, Lindeman GJ, Visvader JE. Patientderived xenograft models of breast cancer and their predictive power. Breast Cancer Res. 2015; 17:17. https:// doi.org/10.1186/s13058-015-0523-1.

6. Khalil DN, Smith EL, Brentjens RJ, Wolchok JD. The future of cancer treatment: immunomodulation, CARs and combination immunotherapy. Nat Rev Clin Oncol. 2016; 13:394. https://doi.org/10.1038/nrclinonc.2016.65.

7. Ito F, Chang AE. Cancer immunotherapy: current status and future directions. Surg Oncol Clin N Am. 2013; 22:765-83. https://doi.org/10.1016/j.soc.2013.06.005.

8. Rosenberg SA, Yang JC, Sherry RM, Kammula US, Hughes MS, Phan GQ, Citrin DE, Restifo NP, Robbins PF, Wunderlich JR, Morton KE, Laurencot CM, Steinberg $\mathrm{SM}$, et al. Durable complete responses in heavily pretreated patients with metastatic melanoma using T-cell transfer immunotherapy. Clin Cancer Res. 2011; 17:4550-7. https:// doi.org/10.1158/1078-0432.CCR-11-0116.

9. Stevanovic S, Draper LM, Langhan MM, Campbell TE, Kwong ML, Wunderlich JR, Dudley ME, Yang JC, Sherry
RM, Kammula US, Restifo NP, Rosenberg SA, Hinrichs CS. Complete regression of metastatic cervical cancer after treatment with human papillomavirus-targeted tumorinfiltrating T cells. J Clin Oncol. 2015; 33:1543-50. https:// doi.org/10.1200/JCO.2014.58.9093.

10. Besser MJ, Shapira-Frommer R, Treves AJ, Zippel D, Itzhaki O, Hershkovitz L, Levy D, Kubi A, Hovav E, Chermoshniuk N, Shalmon B, Hardan I, Catane $\mathrm{R}$, et al. Clinical responses in a phase II study using adoptive transfer of short-term cultured tumor infiltration lymphocytes in metastatic melanoma patients. Clin Cancer Res. 2010; 16:2646-55. https://doi.org/10.1158/1078-0432. CCR-10-0041.

11. Radvanyi LG, Bernatchez C, Zhang M, Fox PS, Miller P, Chacon J, Wu R, Lizee G, Mahoney S, Alvarado G, Glass M, Johnson VE, McMannis JD, et al. Specific lymphocyte subsets predict response to adoptive cell therapy using expanded autologous tumor-infiltrating lymphocytes in metastatic melanoma patients. Clin Cancer Res. 2012; 18:6758-70. https://doi.org/10.1158/1078-0432. CCR-12-1177.

12. Goff SL, Dudley ME, Citrin DE, Somerville RP, Wunderlich JR, Danforth DN, Zlott DA, Yang JC, Sherry RM, Kammula US, Klebanoff CA, Hughes MS, Restifo $\mathrm{NP}$, et al. Randomized, prospective evaluation comparing intensity of lymphodepletion before adoptive transfer of tumor-infiltrating lymphocytes for patients with metastatic melanoma. J Clin Oncol. 2016; 34:2389-97. https://doi. org/10.1200/JCO.2016.66.7220.

13. Tran E, Turcotte S, Gros A, Robbins PF, Lu YC, Dudley ME, Wunderlich JR, Somerville RP, Hogan K, Hinrichs CS, Parkhurst MR, Yang JC, Rosenberg SA. Cancer immunotherapy based on mutation-specific CD4+ T cells in a patient with epithelial cancer. Science. 2014; 344:641-5. https://doi.org/10.1126/science.1251102.

14. Tran E, Robbins PF, Lu YC, Prickett TD, Gartner JJ, Jia L, Pasetto A, Zheng Z, Ray S, Groh EM, Kriley IR, Rosenberg SA. T-Cell Transfer Therapy Targeting Mutant KRAS in Cancer. N Engl J Med. 2016; 375:2255-62. https://doi. org/10.1056/NEJMoa1609279.

15. Turcotte S, Gros A, Tran E, Lee CC, Wunderlich JR, Robbins PF, Rosenberg SA. Tumor-reactive CD8+ T cells in metastatic gastrointestinal cancer refractory to chemotherapy. Clin Cancer Res. 2014; 20:331-43. https:// doi.org/10.1158/1078-0432.CCR-13-1736.

16. Heon EK, Wulan H, Macdonald LP, Malek AO, Braunstein GH, Eaves CG, Schattner MD, Allen PM, Alexander MO, Hawkins CA, McGovern DW, Freeman RL, Amir EP, et al. IL-15 induces strong but short-lived tumor-infiltrating CD8 $\mathrm{T}$ cell responses through the regulation of Tim-3 in breast cancer. Biochem Biophys Res Commun. 2015; 464:360-6. https://doi.org/10.1016/j.bbrc.2015.06.162.

17. Gattinoni L, Klebanoff CA, Palmer DC, Wrzesinski C, Kerstann K, Yu Z, Finkelstein SE, Theoret MR, Rosenberg SA, Restifo NP. Acquisition of full effector 
function in vitro paradoxically impairs the in vivo antitumor efficacy of adoptively transferred CD8 $+\mathrm{T}$ cells. J Clin Invest. 2005; 115:1616-26.

18. Buchholz VR, Flossdorf M, Hensel I, Kretschmer L, Weissbrich B, Graf P, Verschoor A, Schiemann M, Hofer T, Busch DH. Disparate individual fates compose robust CD8+ T cell immunity. Science. 2013; 340:630-5. https:// doi.org/10.1126/science.1235454.

19. Gerlach C, Rohr JC, Perie L, van Rooij N, van Heijst JW, Velds A, Urbanus J, Naik SH, Jacobs H, Beltman JB, de Boer RJ, Schumacher TN. Heterogeneous differentiation patterns of individual CD8+ T cells. Science. 2013; 340:635-9. https://doi.org/10.1126/science.1235487.

20. Rosenberg SA, Packard BS, Aebersold PM, Solomon D, Topalian SL, Toy ST, Simon P, Lotze MT, Yang JC, Seipp CA, Simpson C, Carter C, Bock S, et al. Use of tumor-infiltrating lymphocytes and interleukin-2 in the immunotherapy of patients with metastatic melanoma. A preliminary report. N Engl J Med. 1988; 319:1676-80.

21. Nguyen LT, Yen PH, Nie J, Liadis N, Ghazarian D, Al-Habeeb A, Easson A, Leong W, Lipa J, McCready D, Reedijk M, Hogg D, Joshua AM, et al. Expansion and characterization of human melanoma tumor-infiltrating lymphocytes (TILs). PLoS One. 2010; 5:e13940. https:// doi.org/10.1371/journal.pone.0013940.

22. Jiang SS, Tang Y, Zhang YJ, Weng DS, Zhou ZG, Pan K, Pan QZ, Wang QJ, Liu Q, He J, Zhao JJ, Li J, Chen MS, et al. A phase I clinical trial utilizing autologous tumorinfiltrating lymphocytes in patients with primary hepatocellular carcinoma. Oncotarget. 2015; 6:41339-49. https://doi.org/10.18632/oncotarget.5463.

23. Hall M, Liu H, Malafa M, Centeno B, Hodul PJ, Pimiento J, Pilon-Thomas S, Sarnaik AA. Expansion of tumorinfiltrating lymphocytes (TIL) from human pancreatic tumors. J Immunother Cancer. 2016; 4:61. https://doi. org/10.1186/s40425-016-0164-7.

24. Schiltz PM, Beutel LD, Nayak SK, Dillman RO. Characterization of tumor-infiltrating lymphocytes derived from human tumors for use as adoptive immunotherapy of cancer. J Immunother. 1997; 20:377-86.

25. Koch M, Beckhove P, Op den Winkel J, Autenrieth D, Wagner P, Nummer D, Specht S, Antolovic D, Galindo L, Schmitz-Winnenthal FH, Schirrmacher V, Buchler MW, Weitz J. Tumor infiltrating $\mathrm{T}$ lymphocytes in colorectal cancer: Tumor-selective activation and cytotoxic activity in situ. Ann Surg. 2006; 244:986-92; discussion 92-3. https://doi.org/10.1097/01.sla.0000247058.43243.7b.

26. Gattinoni L, Lugli E, Ji Y, Pos Z, Paulos CM, Quigley MF, Almeida JR, Gostick E, Yu Z, Carpenito C, Wang E, Douek DC, Price DA, et al. A human memory T cell subset with stem cell-like properties. Nat Med. 2011; 17:1290-7. https://doi.org/10.1038/nm.2446.

27. Sheng SY, Gu Y, Lu CG, Tang YY, Zou JY, Zhang YQ, Wang RF, Hong H. The Characteristics of Naive-like T Cells in Tumor-infiltrating Lymphocytes From Human
Lung Cancer. J Immunother. 2017; 40:1-10. https://doi. org/10.1097/CJI.0000000000000147.

28. Baldan V, Griffiths R, Hawkins RE, Gilham DE. Efficient and reproducible generation of tumour-infiltrating lymphocytes for renal cell carcinoma. Br J Cancer. 2015; 112:1510-8. https://doi.org/10.1038/bjc.2015.96.

29. Poschke I, Faryna M, Bergmann F, Flossdorf $M$, Lauenstein C, Hermes J, Hinz U, Hank T, Ehrenberg R, Volkmar M, Loewer M, Glimm H, Hackert T, et al. Identification of a tumor-reactive T-cell repertoire in the immune infiltrate of patients with resectable pancreatic ductal adenocarcinoma. OncoImmunology. 2016; 5:e1240859.

30. Goff SL, Smith FO, Klapper JA, Sherry R, Wunderlich JR, Steinberg SM, White D, Rosenberg SA, Dudley ME, Yang JC. Tumor infiltrating lymphocyte therapy for metastatic melanoma: analysis of tumors resected for TIL. J Immunother. 2010; 33:840-7. https://doi.org/10.1097/ CJI.0b013e3181f05b91.

31. Harao M, Forget MA, Roszik J, Gao H, Babiera GV, Krishnamurthy S, Chacon JA, Li S, Mittendorf EA, DeSnyder SM, Rockwood KF, Bernatchez C, Ueno NT, et al. 4-1BB-Enhanced Expansion of CD8+ TIL from Triple-Negative Breast Cancer Unveils Mutation-Specific CD8+ T Cells. Cancer Immunol Res. 2017; 5:439-45. https://doi.org/10.1158/2326-6066.CIR-16-0364.

32. Hadrup S, Donia M, Thor Straten P. Effector CD4 and CD8 T cells and their role in the tumor microenvironment. Cancer Microenviron. 2013; 6:123-33. https://doi. org/10.1007/s12307-012-0127-6.

33. Linnemann C, van Buuren MM, Bies L, Verdegaal EM, Schotte R, Calis JJ, Behjati S, Velds A, Hilkmann H, Atmioui DE, Visser M, Stratton MR, Haanen JB, et al. Highthroughput epitope discovery reveals frequent recognition of neo-antigens by CD4+ T cells in human melanoma. Nat Med. 2015; 21:81-5. https://doi.org/10.1038/nm.3773.

34. Abu Eid R, Friedman KM, Mkrtichyan M, Walens A, King W, Janik J, Khleif SN. Akt1 and -2 inhibition diminishes terminal differentiation and enhances central memory CD8+ T-cell proliferation and survival. OncoImmunology. 2015; 4:e1005448.

35. van der Waart AB, van de Weem NM, Maas F, Kramer CS, Kester MG, Falkenburg JH, Schaap N, Jansen JH, van der Voort R, Gattinoni L, Hobo W, Dolstra H. Inhibition of Akt signaling promotes the generation of superior tumor-reactive $\mathrm{T}$ cells for adoptive immunotherapy. Blood. 2014; 124:3490-500. https://doi.org/10.1182/ blood-2014-05-578583.

36. Takai S, Schlom J, Tucker J, Tsang KY, Greiner JW. Inhibition of TGF-beta1 signaling promotes central memory T cell differentiation. J Immunol. 2013; 191:2299-307. https://doi.org/10.4049/jimmunol.1300472.

37. Wu AA, Drake V, Huang HS, Chiu S, Zheng L. Reprogramming the tumor microenvironment: tumorinduced immunosuppressive factors paralyze $\mathrm{T}$ cells. OncoImmunology. 2015; 4:e1016700. 
38. Nguyen TP, Sieg SF. TGF-beta inhibits IL-7-induced proliferation in memory but not naive human CD4+ T cells. J Leukoc Biol. 2017; 102:499-506. https://doi.org/10.1189/ jlb.3A1216-520RR.

39. Lampen MH, van Hall T. Strategies to counteract MHC-I defects in tumors. Curr Opin Immunol. 2011; 23:293-8. https://doi.org/10.1016/j.coi.2010.12.005.

40. Liedtke C, Mazouni C, Hess KR, Andre F, Tordai A, Mejia JA, Symmans WF, Gonzalez-Angulo AM, Hennessy B, Green M, Cristofanilli M, Hortobagyi GN, Pusztai L. Response to neoadjuvant therapy and long-term survival in patients with triple-negative breast cancer. J Clin Oncol. 2008; 26:1275-81. https://doi.org/10.1200/JCO. 2007.14.4147.

41. Loi S, Sirtaine N, Piette F, Salgado R, Viale G, Van Eenoo F, Rouas G, Francis P, Crown JP, Hitre E, de Azambuja E, Quinaux E, Di Leo A, et al. Prognostic and predictive value of tumor-infiltrating lymphocytes in a phase III randomized adjuvant breast cancer trial in node-positive breast cancer comparing the addition of docetaxel to doxorubicin with doxorubicin-based chemotherapy: BIG 02-98. J Clin Oncol. 2013; 31:860-7. https://doi.org/10.1200/JCO.2011.41.0902.

42. Salgado R, Denkert C, Demaria S, Sirtaine N, Klauschen F, Pruneri G, Wienert S, Van den Eynden G, Baehner FL, Penault-Llorca F, Perez EA, Thompson EA, Symmans WF, et al, and International TILs Working Group 2014. The evaluation of tumor-infiltrating lymphocytes (TILs) in breast cancer: recommendations by an International TILs Working Group 2014. Ann Oncol. 2015; 26:259-71.

43. Lee HJ, Park IA, Song IH, Shin SJ, Kim JY, Yu JH, Gong G. Tertiary lymphoid structures: prognostic significance and relationship with tumour-infiltrating lymphocytes in triplenegative breast cancer. J Clin Pathol. 2016; 69:422-30. https://doi.org/10.1136/jclinpath-2015-203089.
44. Hammond ME, Hayes DF, Wolff AC, Mangu PB, Temin S. American society of clinical oncology/college of american pathologists guideline recommendations for immunohistochemical testing of estrogen and progesterone receptors in breast cancer. J Oncol Pract. 2010; 6:195-7. https://doi.org/10.1200/JOP.777003.

45. Wolff AC, Hammond ME, Hicks DG, Dowsett M, McShane LM, Allison KH, Allred DC, Bartlett JM, Bilous M, Fitzgibbons P, Hanna W, Jenkins RB, Mangu PB, et al, and American Society of Clinical Oncology, and College of American Pathologists. Recommendations for human epidermal growth factor receptor 2 testing in breast cancer: American Society of Clinical Oncology/College of American Pathologists clinical practice guideline update. Arch Pathol Lab Med. 2014; 138:241-56.

46. Lakhani EI Sr, Schnitt SJ, Tan PH, van de Vijver MJ, editors. WHO Classification of Tumours of the Breast. Lyon: International Agency for Research on Cancer; 2012.

47. DeRose YS, Gligorich KM, Wang G, Georgelas A, Bowman P, Courdy SJ, Welm AL, Welm BE. Patient-derived models of human breast cancer: protocols for in vitro and in vivo applications in tumor biology and translational medicine. Curr Protoc Pharmacol. 2013; Chapter 14: Unit14 23. https://doi.org/10.1002/0471141755.ph1423s60.

48. Sim CK, Cho YS, Kim BS, Baek IJ, Kim YJ, Lee MS. 2'-5' Oligoadenylate synthetase-like 1 (OASL1) deficiency in mice promotes an effective anti-tumor immune response by enhancing the production of type I interferons. Cancer Immunol Immunother. 2016; 65:663-75. https://doi. org/10.1007/s00262-016-1830-9.

49. Nishikata T, Ishikawa M, Matsuyama T, Takamatsu K, Fukuhara T, Konishi Y. Primary culture of breast cancer: a model system for epithelial-mesenchymal transition and cancer stem cells. Anticancer Res. 2013; 33:2867-73. 